\title{
SELECTION OF DWARF MISTLETOE-INFECTED PONDEROSA PINES BY IPS SPECIES (COLEOPTERA: SCOLYTIDAE) IN NORTHERN ARIZONA
}

\author{
Shawn C. Kenaley ${ }^{1,4}$, Robert L. Mathiasen ${ }^{2}$, and Carolyn M. Daugherty ${ }^{3}$
}

\begin{abstract}
Following an Ips bark beetle outbreak in 2002, mortality of ponderosa pine (Pinus ponderosa Douglas ex C. Lawson) was evaluated in 2 study areas infested with southwestern dwarf mistletoe (Arceuthobium vaginatum [Willd.] Presl subsp. cryptopodum [Engelm.] Hawksw. \& Wiens) in the Coconino and Tonto National Forests, Arizona. A pairwise comparison of dwarf mistletoe ratings for live and dead ponderosa pines was conducted to determine whether dead ponderosa pines had higher dwarf mistletoe ratings than pines that were not attacked. In both study areas, dead ponderosa pines had significantly higher dwarf mistletoe ratings, indicating an association between the severity of dwarf mistletoe infection and susceptibility to attack by Ips spp. We suggest that the probability of ponderosa pine mortality is greater in stands severely infested with southwestern dwarf mistletoe in northern Arizona.
\end{abstract}

Key words: Arceuthobium vaginatum, dwarf mistletoe, bark beetles, ponderosa pine, Ips.

In 2002 a bark beetle epidemic severely impacted ponderosa pine (Pinus ponderosa Douglas ex C. Lawson.) forests in northern Arizona. Ponderosa pine mortality occurred over approximately 211,000 ha statewide (USDA 2002). Ips spp. (Ips pini Lecontei and I. lecontei Swaine, Coleoptera: Scolytidae) predominated within infestations and accounted for approximately $99 \%$ or about 208,000 infested hectares statewide (McMillin 2003, S.C. Kenaley personal communication). High rates of infestation and tree mortality occurred within the Coconino (24,400 ha), Prescott (30,600 ha), and Tonto National Forests $(27,000 \mathrm{ha})$. In the Tonto National Forest alone, $47 \%$ of the ponderosa pine forest type was infested, and many stands had mortality rates of $80 \%-90 \%$. Western pine beetle (Dendroctonus brevicomis Leconte), roundheaded pine beetle (Dendroctonus adjunctunus Blandford), and mountain pine beetle (Dendroctonus ponderosae Hopkins) have also been detected within infested areas in northern Arizona, but these bark beetle populations have not yet reached epidemic levels.

In many areas where bark beetle infestations occurred, ponderosa pine mortality was greatest in areas infested with southwestern dwarf mistletoe (Arceuthobium vaginatum
[Willd.] Presl subsp. cryptopodum [Engelm.] Hawksw. \& Wiens). Southwestern dwarf mistletoe is considered to be the most important disease agent of ponderosa pine in the Southwest (Hawksworth 1961, Hawksworth et al. 1989, Hawksworth and Wiens 1996). Severely infected ponderosa pines exhibit an overall decline in tree vigor as expressed via reductions in diameter and height growth, seed and cone production, and longevity (Korstian and Long 1922, Hawksworth 1961, Hessburg et al. 1985, Hawksworth and Geils 1990, Hawksworth and Wiens 1996). Ponderosa pine has a constitutive (preformed) wound response and therefore relies on its primary resin system for defense against bark beetle attack (Matson and Hain 1985). Ponderosa pines severely infected with southwestern dwarf mistletoe may not have the necessary resources to initiate a wound response proportional to bark beetle attack; therefore, the probability of successful bark beetle attack and subsequent mortality of the affected pines increases.

The incidence of bark beetle infestations in areas infested with southwestern dwarf mistletoe has been reported previously for mountain pine beetle (Johnson et al.1976, McCambridge 1980, McCambridge et al. 1982) and for roundheaded pine beetle (Stevens and Flake

\footnotetext{
1Division of Plant and Soil Sciences, West Virginia University, Box 6108, Morgantown, WV 26506-6108.

${ }^{2}$ School of Forestry, Northern Arizona University, Box 15018, Flagstaff, AZ 86001.

${ }^{3}$ Department of Geography, Planning \& Recreation, Northern Arizona University, Box 15016, Flagstaff, AZ 86001.

${ }^{4}$ Present address: Division of Plant and Soil Sciences, 1090 Agricultural Sciences, West Virginia University; Box 6108, Morgantown, WV 26506-6108. E-mail: skenaley@mix.wvu.edu
} 
1974, Negrón 1997, Negrón et al. 2000). Johnson et al. (1976) observed no relationship between dwarf mistletoe and mountain pine beetle attack at low stand mistletoe ratings; however, with increased dwarf mistletoe severity and stand mistletoe rating, bark beetle attacks significantly increased on ponderosa pines infected with dwarf mistletoe. Similarly, McCambridge et al. (1982) found that mortality due to mountain pine beetle was greatest in areas where dwarf mistletoe was most abundant. They found that the percentage killed by mountain pine beetle was greater in ponderosa pine stands infested with southwestern dwarf mistletoe $(30.8 \%)$ than in uninfested stands $(20.5 \%)$. Additionally, losses due to mountain pine beetle attack, as measured by percent of stems killed, merchantable cubic foot volume, and basal area, were significantly higher in study plots infested with dwarf mistletoe. Although these studies were descriptive postmortem evaluations of dwarf mistletoe infection ratings of trees killed by bark beetles, Negrón (1997) constructed predictive models for roundheaded pine beetle infestation in ponderosa pine forests in the Sacramento Mountains, New Mexico, and suggested that the average dwarf mistletoe rating of live ponderosa pines in plots infested with roundheaded pine beetle was slightly higher than in uninfested plots.

No specific studies have examined the relationship between bark beetle attack and ponderosa pine mortality in areas infested with southwestern dwarf mistletoe in northern Arizona. Wagner and Mathiasen (1985) conducted a study comparing dwarf mistletoe ratings (Hawksworth 1977) of live and dead ponderosa pine following a pandora moth (Coloradia pandora pandora Blake, Lepidoptera: Saturniidae) outbreak in 1979 and 1981 on the Kaibab Plateau in northern Arizona. They reported that ponderosa pine mortality primarily occurred among trees severely infected with southwestern dwarf mistletoe. We used methodology similar to Wagner and Mathiasen (1985) to compare attacked and unattacked ponderosa pines to determine if a similar association exists for Ips spp. and dwarf mistletoe-infected ponderosa pines. Our hypothesis was that ponderosa pines attacked and killed by Ips spp. during 2002 were more severely infected with southwestern dwarf mistletoe than pines that were not attacked.

\section{Study Sites}

Two study sites were selected, one approximately $4.8 \mathrm{~km}$ north of Strawberry, Arizona (UTM: 12S 467163E, 3811025N), and the other $12.9 \mathrm{~km}$ northwest of Flagstaff, Arizona (UTM: 12 S 430668E, 3811025N), within the Tonto and Coconino National Forests, respectively. The study sites were selected using insect and disease aerial detection survey maps and were ground-checked for dwarf mistletoe severity (USDA 2002). The sample areas had significant ponderosa pine mortality following the Ips bark beetle outbreak in 2002, ranging in size from 36 ha on the Coconino National Forest to 784 ha on the Tonto National Forest. Both study sites were severely infested with southwestern dwarf mistletoe.

\section{Methods}

The sampling and statistical methods followed those of Wagner and Mathiasen (1985). We sampled the study areas using a systematic distribution of plots with a random start. Plot centers were placed at 40.4-m intervals along a single transect, and plots had a 20.2-m radius. Within each sample plot, a pair consisting of 1 live and 1 dead tree nearest the plot center was selected for comparison. Tree pairs were of similar diameters $( \pm 10.2 \mathrm{~cm})$. If tree mortality could not be attributed to attack by Ips spp. or if a suitable pair was not found, the sample plot was rejected. Diameter at breast height $(\mathrm{dbh} ; 1.4 \mathrm{~m}$ above the ground on the uphill side of the tree) and dwarf mistletoe rating (DMR; Hawksworth 1977) were determined for each tree in all pairings. The dwarf mistletoe rating was applied by dividing the live crown into thirds and rating each third as follows: 0 for no visible dwarf mistletoe infections, 1 for light dwarf mistletoe infection (less than half of the branches were infected), or 2 for severe dwarf mistletoe infection (more than half of the branches were infected). Ratings for each third were then summed to obtain the total rating for the tree. For example, if the bottom third of the live crown was severely infected, the middle third was lightly infected, and the top third had no visible infection, the overall tree rating was 3 (i.e., $2+1+0=3$ ). We examined 22 and 26 sample plots within the Coconino and Tonto National Forests, respectively. 
TABLE 1. Mean diameters (dbh) and dwarf mistletoe ratings (DMR) of live and dead ponderosa pines with corresponding ranges, standard errors of the means $\left(s_{\bar{x}}\right)$, and sign test results $(P$-value, $\alpha=0.05)$, Coconino and Tonto National Forests. Note that ponderosa pine trees killed by Ips spp. (Dead) had significantly higher dwarf mistletoe ratings compared to the paired live trees (Live).

\begin{tabular}{|c|c|c|c|c|c|c|c|c|}
\hline & \multicolumn{4}{|c|}{ Coconino National Forest } & \multicolumn{4}{|c|}{ Tonto National Forest } \\
\hline & \multicolumn{2}{|c|}{ Live } & \multicolumn{2}{|c|}{ Dead } & \multicolumn{2}{|c|}{ Live } & \multicolumn{2}{|c|}{ Dead } \\
\hline & $\mathrm{dbh}(\mathrm{cm})$ & DMR & $\mathrm{dbh}(\mathrm{cm})$ & DMR & $\mathrm{dbh}(\mathrm{cm})$ & DMR & $\mathrm{dbh}(\mathrm{cm})$ & DMR \\
\hline Mean & 11.2 & 3.5 & 11 & 5.8 & 13.7 & 1.6 & 13.1 & 4.4 \\
\hline Range & $5.0-18.3$ & $2.0-6.0$ & $4.0-20.0$ & $4.0-6.0$ & $4.4-26.1$ & $0.0-5.0$ & $5.6-24.4$ & $1.0-6.0$ \\
\hline$s_{\bar{x}}$ & 0.82 & 0.30 & 0.94 & 0.10 & 0.97 & 0.31 & 0.91 & 0.32 \\
\hline$P$-value & \multicolumn{4}{|c|}{$P<0.0001$} & \multicolumn{4}{|c|}{$P<0.0001$} \\
\hline
\end{tabular}

\section{Data Analysis}

We used a nonparametric paired sign test $(\alpha=0.05$; Zar 1999) to compare DMRs of live and dead trees for each study area. (Because we could not assume a normal distribution of the DMRs [nominal-scale data] the pariedsample $t$ test was not appropriate.) Quantitative differences between members of each pair are not important to the sign test, but rather the direction or sign of each difference ( + or -$)$. This test is best used to observe the pronouncement and/or trend of a random variable between members of each pair. The null hypothesis was that there would be no difference in DMR between dead and live ponderosa pines within each study site.

\section{RESUlTS}

Because of the pairing criteria, no difference in mean dbh for live and dead trees was detected (Table 1). Dead ponderosa pines had a consistently higher DMR than their live counterparts in both the Tonto (sign test: $\mathrm{df}=$ 25, $P<0.001$; Table 1) and Coconino National Forests (sign test: $\mathrm{df}=21, P<0.001$; Table 1 ). Furthermore, in only 1 pair per study site did the live tree have a greater DMR than its dead paired member. Overall, dead ponderosa pines were severely infected (mean DMR $=5.8$ ) in the Coconino National Forest and moderately infected (mean DMR $=4.4$ ) in the Tonto National Forest (Table 1).

\section{Discussion}

In ponderosa pine forests of northern Arizona there is a clear association between the severity of southwestern dwarf mistletoe infection and mortality attributable to Ips spp.
In both study areas, ponderosa pine mortality occurred in moderately $(\mathrm{DMR}=4)$ and severely $(\mathrm{DMR}=5-6)$ infected trees. However, those trees that escaped successful attack by Ips spp. had significantly lower mean DMRs. Thus, we suggest that during an Ips spp. outbreak, the risk of ponderosa pine mortality will be greater in trees moderately or severely infected with southwestern dwarf mistletoe.

The sampling scheme and statistical analyses we employed do not allow for the determination of causal relationships; however, southwestern dwarf mistletoe was clearly associated with ponderosa pine mortality during the Ips spp. outbreak in the study areas. The physiological constraints and decline in host vigor imposed by southwestern dwarf mistletoe infection probably contribute to the predisposition of ponderosa pine to bark beetle attack (Hawksworth 1961, Fisher 1983, Hawksworth et al. 1989, Hawksworth and Wiens 1996). Southwestern dwarf mistletoe directly influences the allocation of water and carbohydrates within its host by redistributing water, nutrients, and various organic and inorganic assimilates to infected parts of the tree at the expense of uninfected parts (Hawksworth 1961, Hull and Leonard 1964a, 1964b, Leonard and Hull 1965, Fisher 1983, Knutson 1983, Hawksworth and Wiens 1996, Kolb 2002). With increasing dwarf mistletoe infection, the proportions of carbohydrates partitioned to roots, shoots, reproduction, stem storage, and defensive compounds in ponderosa pine likely decline (Waring and Pitman 1985, Hawksworth and Wiens 1996, Kolb 2001, 2002). This decline is expressed by reductions in diameter and height growth, reduced seed and cone production, and decreased longevity (Korstian and Long 1922, Hawksworth 1961, Hessburg et al. 1985, 
Hawksworth and Geils 1990, Hawksworth and Wiens 1996).

The competition for available carbohydrates between dwarf mistletoe and its host is most apparent in the reduction of diameter growth observed with increasing dwarf mistletoe infection. Across dwarf mistletoe rating classes, Hawksworth (1961) compared the periodic growth rates (last 5 years) in ponderosa pine and found that growth reductions corresponded directly with the degree of infection. Compared to uninfected ponderosa pines $(\mathrm{DMR}=0)$, trees with a DMR $=4,5$, and 6 sustained a $9 \%, 23 \%$, and $53 \%$ reduction in growth, respectively. Poor growth has been associated with bark beetle attacks and the onset of bark beetle outbreaks (Sartwell and Stevens 1975, Larson et al. 1983, Shrimpton and Thompson 1983, Negrón 1997, Negrón et al. 2000). In a model developed to estimate the probabilities of roundheaded pine beetle infestations in ponderosa pine, Negrón (1997) reported that roundheaded pine beetles preferred stands or trees with reduced growth, particularly over the 5 years prior to infestation. Furthermore, Negrón and Wilson (2003) examined the attributes associated with pinyon ips (Ips confusus Leconte) infestation in pinyon pine (Pinus edulis Englem.) in northern Arizona and found that Ips-infested plots had significantly higher pinyon dwarf mistletoe (Arceuthobium divaricatum Engelm.) infection levels, and the probability of pinyon ips attack increased with increasing pinyon dwarf mistletoe infection.

Southwestern dwarf mistletoe is a natural and endemic component of ponderosa pine forests in the Southwest, but in the last century its distribution and intensity of infestation have increased (Andrews and Daniels 1960, Maffei and Beatty 1988). In a survey of National Forest lands in Arizona and New Mexico in 1958, Andrews and Daniels (1960) reported that $30 \%$ of the ponderosa pine forest type was infested with dwarf mistletoe. Maffei and Beatty (1988) reevaluated the survey of Andrews and Daniels (1960) to estimate changes in the incidence of dwarf mistletoe and reported an $8 \%$ increase from 1958 to 1988 and a mean increase of $11 \%$ for the national forests they resampled. Factors contributing to the increased incidence and intensity of southwestern dwarf mistletoe include single tree selection, high-grading, ineffective cultural control, and fire suppres- sion (Alexander and Hawksworth 1975, Maffei and Beatty 1988, Hawksworth et al. 1989). Without appropriate attention and management, southwestern dwarf mistletoe infestations will continue to spread and intensify within ponderosa pine forests of the Southwest. These infestations will then contribute to development of highly susceptible populations of ponderosa pine and increase the risk of ponderosa pine mortality during Ips epidemics as indicated by this study.

Although significant ponderosa pine mortality occurred in northern Arizona in 2002, the current bark beetle outbreak may have beneficial effects in areas infested with southwestern dwarf mistletoe. Southwestern dwarf mistletoe is an obligate parasite of ponderosa pine, and requires a living host to reproduce and persist (Hawksworth 1961, Hawksworth and Wiens 1996). Because Ips spp. are more likely to successfully kill moderately to severely dwarf mistletoe-infected ponderosa pines, we may expect the density of dwarf mistletoeinfested stands to be reduced to some extent. As demonstrated in this study, Ips spp. served as natural thinning agents by selectively killing ponderosa pines moderately to severely infected with dwarf mistletoe. Therefore, the resource environment of surviving trees would probably improve via reductions in both tree density and tree-tree competition for available water and nutrients (Kolb et al. 1998, McMillin and Allen 2004). With the death and ultimate downing of trees both infested with Ips and infected with dwarf mistletoe, healthy or lightly infected trees (DMR $=0-2)$ could experience increased vigor and thus survive (Hawksworth 1961).

Although the susceptibility of individual ponderosa pine trees and ponderosa pine stands to bark beetle attack is also influenced by the interaction of biotic and abiotic factors such as stocking levels, crown class, phloem thickness, resin flow, site quality, and climatic stress (Larson et al. 1983, Lorio 1993, Negrón 1997, Feeney et al. 1998, Kolb et al. 1998, Negrón et al. 2000, Sánchez-Martínez and Wagner 2002), our study demonstrated that southwestern dwarf mistletoe infection was correlated with ponderosa pine mortality during an Ips spp. outbreak in 2 areas in northern Arizona. However, our knowledge regarding southwestern dwarf mistletoe and bark beetle associations is still limited. Future research 
should be devoted to a large-scale examination of the influence(s) of southwestern dwarf mistletoe on ponderosa pine defensive capabilities, and to a spatial analysis of bark beetle infestation in areas containing several different infection levels of southwestern dwarf mistletoe.

\section{ACKNOWLEDGMENTS}

We thank Peter Z. Fulé, Mary Lou Fairweather, Joel McMillin, and Michael R. Wagner for their insightful advice and help with experimental design and locating study sites. Funding for this research was provided by the McIntire-Stennis Program, Northern Arizona University.

\section{Literature Cited}

Alexander, M.E., and F.G. Hawksworth. 1975. Wildland fires and dwarf mistletoes: a literature review of ecology and prescribed burning. General Technical Report RM-GTR-14, USDA Forest Service, Rocky Mountain Forest and Range Experiment Station, Fort Collins, CO. 12 pp.

Andrews, S.R., AND J.P. DANiELs. 1960. A survey of dwarf mistletoe in Arizona and New Mexico. Station Paper No. 49, USDA Forest Service, Rocky Mountain Forest and Range Experiment Station, Fort Collins, CO. 17 pp.

Feeney, S.R., T.E. Kolb, W.W. Covington, and M.R. WAGNER. 1998. Influence of thinning and burning restoration treatments on presettlement ponderosa pines at the Gus Pearson Natural Area. Canadian Journal of Forest Research 28:1295-1306.

Fisher, J.T. 1983. Water relations of mistletoes and their hosts. Pages 161-184 in M. Calder and P. Bernhardt, editors, The biology of mistletoes. Academic Press, Sydney, Australia.

HawksworTh, F.G. 1961. Dwarf mistletoe of ponderosa pine in the Southwest. Technical Bulletin 1246, USDA Forest Service, Washington, DC. 112 pp.

. 1977. The 6-class dwarf mistletoe rating system. General Technical Report RM-GTR-48, USDA Forest Service, Rocky Mountain Forest and Range Experiment Station, Fort Collins, CO. $7 \mathrm{pp}$.

Hawksworth, F.G., and B.W. Geils. 1990. How long do mistletoe-infected ponderosa pines live? Western Journal of Applied Forestry 5:47-48.

Hawksworth, F.G., C.G. Shaw III, and B. Tkacz. 1989. Damage and control of diseases of southwest ponderosa pine. Pages 116-128 in A. Tecle, W.W. Covington, and R.H. Hamre, technical coordinators, Proceedings: multiresource management of ponderosa pine forests. 14-16 November 1989, Flagstaff, AZ. General Technical Report, RM-GTR-185, USDA Forest Service, Rocky Mountain Forest and Range Experiment Station, Fort Collins, CO. 281 pp.

Hawksworth, F.G., AND D. WiEns. 1996. Dwarf mistletoe: biology, pathology, and systematics. Agricultural
Handbook 709. USDA Forest Service, Washington, DC. 409 pp.

Hessburg, P.F., J.S. Beatty, and R.E. Wood. 1985. Incidence, severity, and growth losses associated with ponderosa pine dwarf mistletoe on the Apache-Sitgreaves National Forests, Arizona. Forest Pest Management Report R3-85-10, USDA Forest Service, Southwestern Region, Albuquerque, NM. 32 pp.

Hull, R.J., AND O.A. LEONARD. 1964a. Physiological aspects of parasitism in mistletoes (Arceuthobium and Phoradendron). I. The carbohydrate nutrition of mistletoe. Plant Physiology 39:996-1007.

. 1964b. Physiological aspects of parasitism in mistletoes (Arceuthobium and Phoradendron). II. The photosynthetic capacity of mistletoe. Plant Physiology 39:1008-1017.

Johnson, D.W., L.C. Yarger, C.D. Minnemeyer, And V.E. PACE. 1976. Dwarf mistletoe as a predisposing factor for mountain pine beetle attack of ponderosa pine in the Colorado Front Range. Forest Insect and Disease Technical Report R-2-4, USDA Forest Service, Rocky Mountain Forest and Range Experiment Station, Fort Collins, CO. 7 pp.

Knutson, D.M. 1983. Physiology of mistletoe parasitism and disease response in the host. Pages 298-316 in M. Calder and P. Bernhardt, editors, The biology of mistletoes. Academic Press, Sydney, Australia.

KOLB, T.E. 2001. Linkages between tree stress and defensive processes in southwestern ponderosa pine. Pages 171-172 in Boreal odyssey: proceedings of the North American Forest Insect Work Conference, 14-18 May 2001. Information Report NOR-X-381. Natural Resources Canada, Canadian Forest Service, Edmonton, Alberta.

2002. Ecofisiologica del parasitismo en el reino vegetal. Pages 57-85 in A. Saez-Lopez and P. Catalan, editors, Plantas parasitias del la Peninsula Iberica e Islas Baleares. Mundi-Prensa, Madrid, Spain.

Kolb, T.E., K.M. Holmberg, M.R. Wagner, and J.E. STONE. 1998. Regulation of ponderosa pine foliar physiology and insect resistance mechanisms by basal area treatments. Tree Physiology 18:375-381.

Konstian, C.F., And W.H. Long. 1922. The western yellow pine mistletoe: effect on growth and suggestions for control. USDA Bulletin 1112, Washington, DC. $35 \mathrm{pp}$.

Larson, S., R. Oren, R.H. Waring, and J.W. Barrett. 1983. Attacks of mountain pine beetle as related to tree vigor of ponderosa pine. Forestry Science 29: 395-402.

LeOnard, O.A., AND R.J. Hull. 1965. Translocation relationships in and between mistletoes and their hosts. Hilgardia 37:115-153.

LORIO, P.L., JR. 1993. Environmental stress and wholetree physiology. Pages 81-101 in T.D. Schowalter and G.M. Filip, editors, Beetle-pathogen interactions in conifer forests. Academic Press, London, England.

Maffei, J.R., and J. Beatty. 1988. Changes in the incidence of dwarf mistletoe over 30 years in the Southwest. Pages 88-90 in B.J. van der Kamp, composer, Proceedings: 36th Annual Western International Forest Disease Work Conference, 19-23 September 1988, Park City, Utah.

Matson, P.A., AND F.P. Hain. 1985. Host conifer defense strategies: a hypothesis. Pages 33-42 in L. Saftanyik, 
technical coordinator, Proceedings of the International Union of Forestry Research Organizations conference on the role of the host in the population dynamics of forest insects, Pacific Forest Research Centre, Victoria, British Columbia, Canada.

McCambridge, W.F. 1980. Some mountain pine beetle infestation characteristics in dwarf mistletoe-infected and uninfected ponderosa pine. Research Note RMRN-391, USDA Forest Service, Rocky Mountain Forest and Range Experiment Station, Fort Collins, CO. 3 pp.

McCambridge, W.F., F.G. Hawksworth, C.B. EdminSTER, AND J.G. LAUT. 1982. Ponderosa pine mortality resulting from a mountain pine beetle outbreak. Research Paper RM-RP-235, USDA Forest Service, Rocky Mountain Forest and Range Experiment Station, Fort Collins, CO. 7 pp.

McMillin, J.D., AND K.K. AlLEn. 2004. Effects of Douglas-fir beetle (Coleoptera: Scolytidae) infestations on forest overstory and understory conditions in western Wyoming. Western North American Naturalist 63:498-506.

NEgRón, J. 1997. Estimating probabilities of infestation and extent of damage by the roundheaded pine beetle in ponderosa pine in the Sacramento Mountains, New Mexico. Canadian Journal of Forest Research 27:1936-1945.

Negrón, J., J.L. Wilson, And J.A. Anhold. 2000. Stand conditions associated with roundheaded pine beetle (Coleoptera: Scolytidae) infestations in Arizona and Utah. Environmental Entomology 29:20-27.

Negrón, J.F., AND J.L. Wilson. 2003. Attributes associated with probability of infestation by the piñon ips, Ips confusus (Coleoptera: Scolytidae), in piñon pine,
Pinus edulis. Western North American Naturalist 63: 440-451.

SÁnchez-Martínez, G., And M.R. Wagner. 2002. Bark beetle community structure under four ponderosa pine forest stand conditions in northern Arizona. Forest Ecology and Mangement 170:145-160.

Sartwell, J.M., AND R.E. Stevens. 1975. Mountain pine beetle in ponderosa pine, prospects for silvicultural control in second growth stands. Journal of Forestry 73:136-140.

Shrimpton, D.M., AND A.J. Thompson. 1983. Growth characteristics of lodgepole pine associated with the start of mountain pine beetle outbreaks. Canadian Journal of Forest Research 13:137-144.

Stevens, R.E., And H.W. Flake. 1974. A roundheaded pine beetle outbreak in New Mexico: associated stand conditions and impact. Research Note RM-RN-259, USDA Forest Service, Rocky Mountain Forest and Range Experiment Station, Fort Collins, CO. 4 pp.

USDA. 2002. Annual aerial insect and disease detection survey maps. USDA Forest Service, Region 3, Flagstaff, AZ

Wagner, M.R., and R.L. Mathiasen. 1985. Dwarf mistletoe-pandora moth interaction and its contribution to ponderosa pine mortality in Arizona. Great Basin Naturalist 45:423-426.

Waring, R.H., and G.B. Pitman. 1985. Modifying lodgepole pine stands to change susceptibility to mountain pine beetle attack. Ecology 66:889-897.

ZaR, J.H. 1999. Biostatistical analysis. Prentice-Hall, Inc., Upper Saddle River, NJ.

Received 13 May 2005 Accepted 17 January 2006 